\title{
Seroma following transabdominal preperitoneal patch plasty (TAPP): incidence, risk factors, and preventive measures
}

\author{
F. Köckerling ${ }^{1} \cdot$ R. Bittner ${ }^{2} \cdot$ D. Adolf ${ }^{3} \cdot$ R. Fortelny ${ }^{4} \cdot$ H. Niebuhr ${ }^{5} \cdot$ F. Mayer $^{6} \cdot$ C. Schug-Pass $^{1}$
}

Received: 7 May 2017 / Accepted: 3 October 2017 / Published online: 26 October 2017

(c) The Author(s) 2018. This article is an open access publication

\begin{abstract}
Background The reported range of seroma formation in the literature after TEP repair is between 0.5 and $12.2 \%$ and for TAPP between 3.0 and $8.0 \%$. Significant clinical factors associated with seroma formation include old age, a large hernia defect, an extension of the hernia sac into the scrotum, as well as the presence of a residual indirect sac. Seroma formation is a frequent complication of laparoendoscopic mesh repair of moderate to large-size direct (medial) inguinal hernia defects. This present analysis of data from the Herniamed Hernia Registry now explores the influencing factors for seroma formation in male patients after TAPP repair of primary unilateral inguinal hernia.

Methods In total, 20,004 male patients with TAPP repair of primary unilateral inguinal hernia were included in uni- and multivariable analysis.

Results Univariable analysis revealed the highly significant impact of the fixation technique on the seroma rate (non-fixation $0.7 \%$ vs. tacks $2.1 \%$ vs. glue $3.9 \% ; p<0.001$ ). Multivariable analysis showed that glue compared to tacks (OR 2.077 [1.650; 2.613]; $p<0.001)$ and non-fixation (OR 5.448 [4.056; 7.317]; $p<0.001)$ led to an increased seroma rate. A large hernia defect (III vs. I: OR 2.868 [1.815; 4.531]; $p<0.001$; II vs. I: OR 2.157 [1.410; 3.300]; $p<0.001$ ) presented a significantly higher risk of seroma formation. Likewise, medial compared to lateral inguinal hernias had a higher seroma rate (OR 1.272 [1.020; 1.585$] ; p=0.032$ ).

Conclusions Mesh fixation with tacks or glue, a larger hernia defect, and medial defect localization present a higher risk for seroma development in TAPP inguinal hernia repair.
\end{abstract}

Keywords Inguinal hernia $\cdot$ TAPP $\cdot$ Seroma $\cdot$ Complications $\cdot$ Mesh fixation

F. Köckerling

ferdinand.koeckerling@vivantes.de

1 Department of Surgery and Center for Minimally Invasive Surgery, Academic Teaching Hospital of Charité Medical School, Vivantes Hospital, Neue Bergstrasse 6, 13585 Berlin, Germany

2 Hernia Center, Winghofer Medicum, Winghofer Strasse 42, 72108 Rottenburg am Neckar, Germany

3 StatConsult $\mathrm{GmbH}$, Halberstädter Strasse 40 a, 39112 Magdeburg, Germany

4 Department of General, Visceral and Oncologic Surgery, Wilhelminenhospital, Montleartstrasse 37, 1160 Vienna, Austria

5 Hanse-Hernia Center, Alte Holstenstrasse 16, 21031 Hamburg, Germany

6 Department of Surgery, Paracelsus Medical University, Müllnerhauptstrasse 48, 5020 Salzburg, Austria
According to the Guidelines of the International Endohernia Society (IEHS) and the European Association of Endoscopic Surgery (EAES) [1-3], seroma formation is a frequent occurrence after laparoendoscopic groin hernia repair but lacks clinical relevance or significance in most cases. It is advised to explain the possibility of seroma formation to the patient before surgery to prevent anxiety [3]. The main problem with postoperative seroma is the perception by patients and their general practitioners that they represent a persistence or recurrence of the hernia [4]. There are reports of seroma being mistaken for recurrences following laparoscopic hernia repair, with the correct diagnosis being made only after groin exploration [4].

The reported range of seroma formation in literature reviews after TEP repair is between 0.5 and $12.2 \%$ [5] and for TAPP between 3.0 and $8.0 \%$ [4]. In a meta-analysis of randomized controlled trials, a significantly higher incidence of seromas was found after laparoendoscopic inguinal hernia 
repair, with 1590 patients, versus Lichtenstein repair, with 1620 patients (12.2 vs. $8.9 \% ; p=0.003$ ) [6]. If no measures are taken for prevention of seroma after TEP or TAPP repair for direct inguinal hernia, the incidence reported is $4-5 \%$ [7]. In large registry studies of primary unilateral inguinal hernia repair in men with the laparoendoscopic technique, the incidence of seroma has been reported as $0.5 \%$ for TEP and $3 \%$ for TAPP $[8,9]$. Significant clinical factors associated with seroma formation include old age, a large hernia defect, an extension of the hernia sac into the scrotum, and the presence of a residual distal indirect sac $[10,11]$. Seroma formation is a frequent complication of laparoendoscopic mesh repair of moderate to large size direct medial inguinal hernia defects [5].

While certain studies had identified significantly less seroma formation on using extra lightweight meshes [12], a meta-analysis did not note any difference in the impact of lightweight vs heavyweight meshes on the seroma rate after laparoendoscopic inguinal hernia repair [13]. Likewise, while in one observational study comparison of mesh fixation versus non-fixation for endoscopic inguinal hernia repair revealed a lower seroma rate for non-fixation [14], this was not demonstrated by a corresponding meta-analysis [15]. Besides, comparison of mesh fixation with tacks versus glue did not show any significant difference in the seroma rate [16-18]. In two observational studies, preperitoneal drainage was found to have a positive effect on the seroma incidence [19, 20].

This present analysis of data from the Herniamed Hernia Registry now explores the influencing factors for seroma formation after TAPP repair. Preventative measures will then be discussed.

\section{Materials and methods}

As of October 10, 2016, 577 participating hospitals and office-based surgeons mainly from Germany, Austria, and Switzerland have entered prospective data into the multicenter internet-based Herniamed Hernia Registry on their patients who had undergone routine hernia surgery and signed an informed consent agreeing to participate [21]. As part of the information provided to patients regarding participation in the Herniamed Quality Assurance Study and signing the informed consent declaration, all patients are informed that the treating hospital or medical practice would like to be informed about any problems occurring after the operation and that the patient has the opportunity to attend clinical examination. All postoperative complications occurring up to 30 days after surgery are recorded. This present study analyzed the prospective data collected for all male patients who had been operated on with a TAPP technique for repair of a primary unilateral inguinal hernia in the period September 1, 2009, up to and including September 1, 2015. At 1-year follow-up, the general practitioners and patients were asked once again for any postoperative complication. If complications are reported by the general practitioner or patient, patients can be requested to attend clinical and/or radiological examinations. A recent publication has provided impressive evidence of the role of patient-reported outcomes [22]. Only those patients for whom 1-year follow-up results were available were included in the analysis. Other inclusion criteria were as follows: age $\geq 16$ years and only medial/ lateral/combined types of inguinal hernia based on the EHS classification [23]. In total, 20,004 patients were included in uni- and multivariable analysis (Fig. 1) for investigation of influencing factors for the development of a seroma after TAPP inguinal hernia repair. During the observation period, the 20,004 TAPP procedures were performed in 8799 patients (44.0\%) without mesh fixation, in 6387 patients (31.9\%) using tacks for fixation, and in 4818 patients with glue fixation (24.1\%).

The most commonly used meshes $(\geq 2 \%)$ are given in Table 1 . These were mainly large-pore lightweight meshes. The most commonly used $(\geq 2 \%)$ tacks and glues are listed in Tables 2 and 3, respectively.

All analyses were performed with the software SAS 9.4 (SAS institute Inc. Cary, NC, USA) and intentionally calculated to a full significance level of $5 \%$, i.e., they were not corrected in respect of multiple tests, and each $p$ value 0.05 represents a significant result. To first discern the differences between the groups in unadjusted analyses. Fisher's exact test was used for categorical outcome variables, and the robust $t$ test (Satterthwaite) for continuous variables. For mesh size $\left(\mathrm{cm}^{2}\right)$, a logarithmic transformation was applied and re-transformed mean and range of dispersion are given.

To identify influence factors in multivariable analysis of seroma, a binary logistic regression model was used. Potential influence factors were: ASA score (I/II/III/IV), age (years), BMI $\left(\mathrm{kg} / \mathrm{m}^{2}\right)$, mesh size $\left(\mathrm{cm}^{2}\right)$, defect size (I/II/III), risk factors (yes/no), preoperative pain (yes/no/ unknown), EHS classification (lateral/medial/combined), drainage (yes/no), and mesh fixation (non-fixation/tacks/ glue). Estimates for odds ratio (OR) and the corresponding 95\% confidence interval based on the Wald test were given. For influence variables with more than two categories, pairwise odds ratios were given. For age (years), the 10-year OR estimate, for BMI $\left(\mathrm{kg} / \mathrm{m}^{2}\right)$ the five-point OR estimate, and for mesh size $\left(\mathrm{cm}^{2}\right)$ the 10-point OR estimate were given. Results are presented in tabular form, sorted by descending impact. 


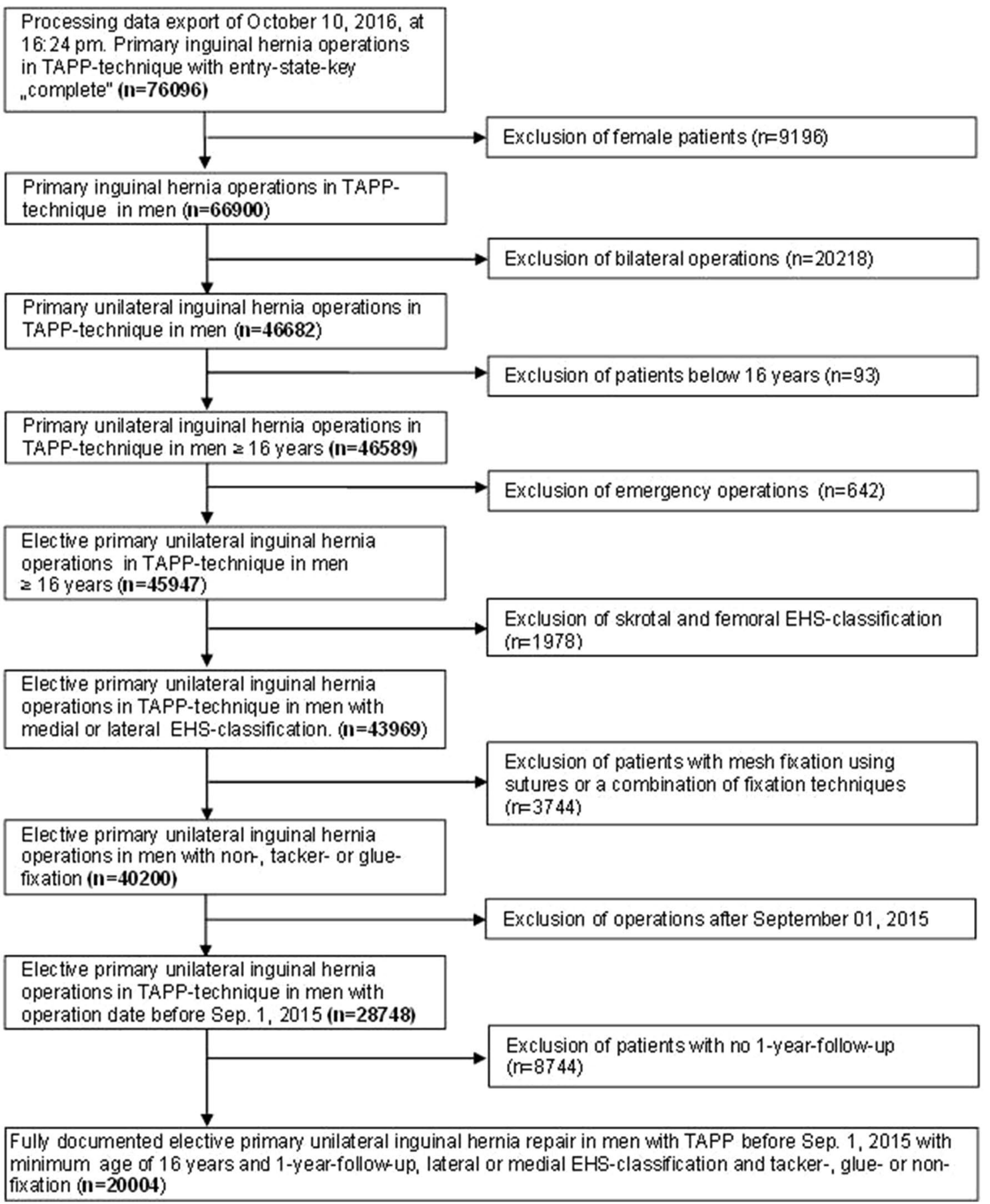

Fig. 1 Flowchart of patient inclusion

\section{Results}

\section{Univariable analysis}

Univariable analysis of the relationship between the fixation technique (non-fixation/tacks/glue) and the patient and operative characteristics revealed highly significant differences (Tables 4, 5). For example, the proportion of patients with tacks or glue fixation for large hernia defects (EHS III $>3 \mathrm{~cm}$ ) was significantly greater than that with non-fixation (Table 5). Likewise, the proportion of medial EHS classifications was higher in the tacks and glue mesh fixation group than in the no mesh fixation group. Drain placement was more common in cases of no mesh fixation (Table 5). With regard to mesh fixation (non-fixation/ tacks/glue), highly significant differences were seen in 
Table 1 Proportion of meshes most commonly used $(\geq 2 \%)$

\begin{tabular}{|c|c|c|c|c|c|c|c|c|}
\hline \multirow[t]{3}{*}{ Type of mesh } & \multicolumn{6}{|c|}{ Type of fixation } & \multirow{2}{*}{\multicolumn{2}{|c|}{ Total }} \\
\hline & \multicolumn{2}{|c|}{ Non-fixation } & \multicolumn{2}{|l|}{ Tacks } & \multicolumn{2}{|l|}{ Glues } & & \\
\hline & $N$ & $\%$ & $N$ & $\%$ & $N$ & $\%$ & $N$ & $\%$ \\
\hline Prolene & 12 & 0.1 & 447 & 7.0 & 6 & 0.1 & 465 & 2.3 \\
\hline Ultrapro & 1139 & 12.9 & 1770 & 27.7 & 2112 & 43.8 & 5021 & 25.1 \\
\hline Parietene standard & 297 & 3.4 & 240 & 3.8 & 10 & 0.2 & 547 & 2.7 \\
\hline Parietex ProGrip & 1017 & 11.6 & 11 & 0.2 & 8 & 0.2 & 1036 & 5.2 \\
\hline Parietene ProGrip & 1332 & 15.1 & 29 & 0.5 & 1 & 0.0 & 1362 & 6.8 \\
\hline Parietene light & 468 & 5.3 & 414 & 6.5 & 70 & 1.5 & 952 & 4.8 \\
\hline DynaMesh-ENDOLAP & 219 & 2.5 & 366 & 5.7 & 409 & 8.5 & 994 & 5.0 \\
\hline TiMesh extralight & 260 & 3.0 & 85 & 1.3 & 383 & 7.9 & 728 & 3.6 \\
\hline TiMesh light & 646 & 7.3 & 569 & 8.9 & 222 & 4.6 & 1437 & 7.2 \\
\hline 3DMax light & 1007 & 11.4 & 398 & 6.2 & 146 & 3.0 & 1551 & 7.8 \\
\hline Optilene & 129 & 1.5 & 226 & 3.5 & 208 & 4.3 & 563 & 2.8 \\
\hline Optilene LP & 326 & 3.7 & 651 & 10.2 & 733 & 15.2 & 1710 & 8.5 \\
\hline TiO2Mesh & 460 & 5.2 & 86 & 1.3 & 115 & 2.4 & 661 & 3.3 \\
\hline Other meshes & 1487 & 16.9 & 1095 & 17.1 & 395 & 8.2 & 2977 & 14.9 \\
\hline Total & 8799 & 100.0 & 6387 & 100.0 & 4818 & 100.0 & 20,004 & 100.0 \\
\hline
\end{tabular}

\begin{tabular}{lrr}
\hline Type of tacks & \multicolumn{2}{c}{$\%$} \\
\hline ProTack & 348 & 5.4 \\
Endo universal & 531 & 8.3 \\
AbsorbaTack & 2845 & 44.5 \\
PermaSorb & 318 & 5.0 \\
EMS stapler & 1299 & 20.3 \\
SorbaFix & 568 & 8.9 \\
SecureStrap & 328 & 5.1 \\
Others & 150 & 2.3 \\
Total & 6387 & 100.0 \\
\hline
\end{tabular}

Table 2 Proportion of tacks most commonly used $(\geq 2 \%)$

Table 3 Proportion of glue most commonly used $(\geq 2 \%)$

\begin{tabular}{lrr}
\hline Type of glue & \multicolumn{2}{l}{$\%$} \\
\hline Tissucol/tisseel & 2050 & 42.5 \\
Glubran 2 & 652 & 13.5 \\
Evicel & 1607 & 33.4 \\
Liquiband FIX8 & 161 & 3.3 \\
Others & 348 & 7.2 \\
Total & 4818 & 100.0 \\
\hline
\end{tabular}

the overall postoperative complication rate (non-fixation $1.8 \%$ vs. tacks $3.0 \%$ vs. glue $4.8 \% ; p<0.001$ ) (Table 6). Seroma accounted for the greatest proportion of postoperative complications (non-fixation $0.7 \%$ vs. tacks $2.1 \%$ vs. glue $3.9 \%) ; p<0.001$ ).

\section{Multivariable analysis}

The results of multivariable analysis of the postoperative com(model fit: $p<0.001$ ). The fixation technique and hernia defect size exerted a highly significant influence on seroma formation (in each case $p<0.001$ ). Glue compared to tacks (OR 2.077 [1.650; 2.613]; $p<0.001)$ and glue vs non-fixation (OR 5.448 [4.056; 7.317]; $p<0.001)$ resulted in an increased seroma rate. Similarly, tacks compared to non-fixation (OR 2.623 [1.925; 3.575]; $p<0.001$ ) were associated with a higher risk of seroma formation. A large hernia defect (III vs. I: OR 2.868 [1.815; 4.531]; $p<0.001$; II vs. I: OR 2.157 [1.410; 3.300]; $p<0.001$ ) presented a significantly higher risk of seroma formation. That was also true for medial compared to lateral inguinal hernia (medial vs. lateral: OR 1.272 [1.020; 1.585]; $p=0.032$ ), and for medial compared to combined (medial vs. combined: OR 2.194 [1.388; 3.470]; $p<0.001)$. Besides, a high ASA score (ASA III/IV vs. I: OR $1.645[1.109 ; 2.442] ; p=0.013$ ) led to an increased risk of seroma formation. The presence of risk factors (yes vs. no: OR 0.703 [0.543; 0.910]; $p=0.008$ ) reduced the risk of seroma development. Only a trend towards a reduction in the risk of seroma formation was identified for the use of a drain (OR 0.584 [0.319; 1.072]; $p=0.083$ ).

\section{Discussion}

This present analysis of data from the Herniamed Hernia Registry reveals highly significant differences in the postoperative complication rate in relation to the fixation technique plications associated with seroma are summarized in Table 7 
Table 4 Mean age, BMI, and mesh size in male patients with primary unilateral inguinal hernia repair in TAPP technique

\begin{tabular}{lllll}
\hline & Non-fixation & Tacker & Glue & $p$ \\
\hline $\begin{array}{l}\text { Age (years) } \\
\text { Median } \pm \text { STD }\end{array}$ & $55.0 \pm 15.6$ & $58.8 \pm 14.7$ & $56.4 \pm 15.0$ & $<.001$ \\
$\begin{array}{c}\text { BMI } \\
\text { Mean } \pm \text { STD }\end{array}$ & $25.9 \pm 3.3$ & $26.0 \pm 3.4$ & $25.8 \pm 3.4$ & $<.001$ \\
$\begin{array}{c}\text { Mesh size }\left(\mathrm{cm}^{2}\right) \\
\begin{array}{c}\text { Mean }(\text { range of } \\
\text { dispersion) }\end{array}\end{array}$ & $146.3(145.2 ; 147.5)$ & $149.9(148.7 ; 151.1)$ & $151.1(150.1 ; 152.2)$ & $<.001$ \\
\hline
\end{tabular}

\begin{tabular}{|c|c|c|c|c|c|c|c|}
\hline & \multicolumn{2}{|c|}{ Non-fixation } & \multicolumn{2}{|l|}{ Tacks } & \multicolumn{2}{|l|}{ Glue } & \multirow[t]{2}{*}{$p$} \\
\hline & $n$ & $\%$ & $n$ & $\%$ & $n$ & $\%$ & \\
\hline \multicolumn{8}{|l|}{ ASA score } \\
\hline I & 3043 & 34.58 & 1864 & 29.18 & 1946 & 40.39 & \multirow[t]{3}{*}{$<.001$} \\
\hline II & 4737 & 53.84 & 3621 & 56.69 & 2461 & 51.08 & \\
\hline III/IV & 1019 & 11.58 & 902 & 14.12 & 411 & 8.53 & \\
\hline \multicolumn{8}{|l|}{ Defect size } \\
\hline $\mathrm{I}(<1.5 \mathrm{~cm})$ & 1533 & 17.42 & 727 & 11.38 & 683 & 14.18 & \multirow[t]{3}{*}{$<.001$} \\
\hline II $(1.5-3 \mathrm{~cm})$ & 6072 & 69.01 & 3939 & 61.67 & 3200 & 66.42 & \\
\hline III $(>3 \mathrm{~cm})$ & 1194 & 13.57 & 1721 & 26.95 & 935 & 19.41 & \\
\hline \multicolumn{8}{|c|}{ EHS classification } \\
\hline Combined & 1128 & 12.82 & 633 & 9.91 & 394 & 8.18 & \multirow[t]{3}{*}{$<.001$} \\
\hline Lateral & 5483 & 62.31 & 3718 & 58.21 & 3142 & 65.21 & \\
\hline Medial & 2188 & 24.87 & 2036 & 31.88 & 1282 & 26.61 & \\
\hline \multicolumn{8}{|l|}{ Drainage } \\
\hline Yes & 736 & 8.36 & 346 & 5.42 & 148 & 3.07 & \multirow[t]{2}{*}{$<.001$} \\
\hline No & 8063 & 91.64 & 6041 & 94.58 & 4670 & 96.93 & \\
\hline \multicolumn{8}{|l|}{ Risk factors $^{\mathrm{a}}$} \\
\hline \multicolumn{8}{|l|}{ Total } \\
\hline Yes & 2248 & 25.55 & 1665 & 26.07 & 1233 & 25.59 & \multirow[t]{2}{*}{0.747} \\
\hline No & 6551 & 74.45 & 4722 & 73.93 & 3585 & 74.41 & \\
\hline
\end{tabular}

${ }^{a}$ COPD, diabetes, aortic aneurysm, immunosuppression, corticoid medication, smoking, coagulopathy, antiplatelet medication, anticoagulation therapy
Table 5 Patient and operative characteristics in relation to mesh fixation, including unadjusted tests for significant differences for male patients with TAPP repair of primary unilateral inguinal hernia. For example, the overall postoperative complication rate for non-fixation was $1.8 \%$, for tack fixation $3.0 \%$, and for glue fixation $4.8 \%(p<0.001)$. Seroma accounted for the greatest proportion of postoperative complications. Here, too, a highly significant difference was detected in relation to mesh fixation (non-fixation $0.7 \%$ vs. tacks $2.1 \%$ vs. glue $3.9 \%$; $p<0.001$ ). Multivariable analysis confirmed the highly significant influence exerted by the fixation technique on the seroma rate. Glue compared to tacks and non-fixation resulted in a higher seroma rate. But also tacks compared to non-fixation led to a higher seroma rate. Accordingly, no mesh fixation clearly had the lowest seroma rate. That could be one explanation for the lower seroma rates after TEP than after TAPP [8], since as per the guidelines $[1,2]$ mesh fixation is rarely used for TEP, whereas as evidenced by the present data this continues to be used in $65 \%$ of cases for TAPP [24]. But the evidencebased data demonstrate that even for TAPP mesh fixation can be omitted for hernia defects up to $3 \mathrm{~cm}$ (EHS LI, II and MI, II) [1, 2]. Based on the registry data only a defect size of more than $3 \mathrm{~cm}$ (EHS LIII, MIII), and here in particular medial and combined defects, requires mesh fixation [24]. Accordingly, as for TEP, mesh fixation can be dispensed with more often for TAPP, too. With a current proportion that continues to be as high as $65 \%$ [24], the fixation rate can still be markedly reduced for TAPP. Omission of fixation might then positively impact the seroma rate after TAPP.

Naturally, smaller defects also present a lower risk of seroma formation, as do lateral compared to medial inguinal hernias. Lateral defects in line with the anatomy of the groin have a curtain-like closure after excision of the hernia 
Table 6 Outcome variables in relation to mesh fixation, including unadjusted tests for significant differences

\begin{tabular}{|c|c|c|c|c|c|c|c|}
\hline & \multicolumn{2}{|c|}{ Non-fixation } & \multicolumn{2}{|c|}{ Tacks } & \multicolumn{2}{|l|}{ Glue } & \multirow[t]{2}{*}{$\mathrm{p}$} \\
\hline & $n$ & $\%$ & $n$ & $\%$ & $n$ & $\%$ & \\
\hline \multicolumn{8}{|c|}{ Postoperative complications } \\
\hline \multicolumn{8}{|l|}{ Total } \\
\hline Yes & 159 & 1.81 & 192 & 3.01 & 231 & 4.79 & \multirow[t]{2}{*}{$<.001$} \\
\hline No & 8640 & 98.19 & 6195 & 96.99 & 4587 & 95.21 & \\
\hline \multicolumn{8}{|c|}{ Bleeding } \\
\hline Yes & 76 & 0.86 & 50 & 0.78 & 34 & 0.71 & \multirow[t]{2}{*}{0.602} \\
\hline No & 8723 & 99.14 & 6337 & 99.22 & 4784 & 99.29 & \\
\hline \multicolumn{8}{|c|}{ Seroma } \\
\hline Yes & 61 & 0.69 & 133 & 2.08 & 189 & 3.92 & \multirow[t]{2}{*}{$<.001$} \\
\hline No & 8738 & 99.31 & 6254 & 97.92 & 4629 & 96.08 & \\
\hline \multicolumn{8}{|c|}{ Infection } \\
\hline Yes & 6 & 0.07 & 7 & 0.11 & 2 & 0.04 & \multirow[t]{2}{*}{0.407} \\
\hline No & 8793 & 99.93 & 6380 & 99.89 & 4816 & 99.96 & \\
\hline \multicolumn{8}{|l|}{ Bowel } \\
\hline Yes & 9 & 0.10 & 1 & 0.02 & 1 & 0.02 & \multirow[t]{2}{*}{0.041} \\
\hline No & 8790 & 99.90 & 6386 & 99.98 & 4817 & 99.98 & \\
\hline \multicolumn{8}{|c|}{ Wound healing disorders } \\
\hline Yes & 7 & 0.08 & 5 & 0.08 & 8 & 0.17 & \multirow[t]{2}{*}{0.250} \\
\hline No & 8792 & 99.92 & 6382 & 99.92 & 4810 & 99.83 & \\
\hline \multicolumn{8}{|l|}{ Ileus } \\
\hline Yes & 8 & 0.09 & 2 & 0.03 & 3 & 0.06 & \multirow[t]{2}{*}{0.362} \\
\hline No & 8791 & 99.91 & 6385 & 99.97 & 4815 & 99.94 & \\
\hline
\end{tabular}

Table 7 Multivariable analysis of seroma formation following TAPP inguinal hernia repair

\begin{tabular}{|c|c|c|c|c|c|c|}
\hline Parameter & $p$ Value & Category & $p$ Value paired & OR estimate & $95 \%$-CI & \\
\hline \multirow[t]{3}{*}{ Fixation } & \multirow[t]{3}{*}{$<.001$} & Glue vs. tacks & $<.001$ & 2.077 & 1.650 & 2.613 \\
\hline & & Glue vs. non-fixation & $<.001$ & 5.448 & 4.056 & 7.317 \\
\hline & & Tacks vs. non-fixation & $<.001$ & 2.623 & 1.925 & 3.575 \\
\hline \multirow[t]{3}{*}{ Defect size } & \multirow[t]{3}{*}{$<.001$} & III $(>3 \mathrm{~cm})$ vs. II $(1.5-3 \mathrm{~cm})$ & 0.018 & 1.330 & 1.050 & 1.684 \\
\hline & & III $(>3 \mathrm{~cm})$ vs. I $(<1.5 \mathrm{~cm})$ & $<.001$ & 2.868 & 1.815 & 4.531 \\
\hline & & II $(1.5-3 \mathrm{~cm})$ vs. I $(<1.5 \mathrm{~cm})$ & $<.001$ & 2.157 & 1.410 & 3.300 \\
\hline \multirow[t]{3}{*}{ EHS classification } & \multirow[t]{3}{*}{0.002} & Lateral vs. combined & 0.016 & 1.725 & 1.108 & 2.686 \\
\hline & & Medial vs. lateral & 0.032 & 1.272 & 1.020 & 1.585 \\
\hline & & Medial vs. combined & $<.001$ & 2.194 & 1.388 & 3.470 \\
\hline Risk factors & 0.008 & Yes vs. no & & 0.703 & 0.543 & 0.910 \\
\hline \multirow[t]{3}{*}{ ASA score } & \multirow[t]{3}{*}{0.035} & III/IV vs. II & 0.166 & 1.258 & 0.909 & 1.742 \\
\hline & & III/IV vs. I & 0.013 & 1.645 & 1.109 & 2.442 \\
\hline & & II vs. I & 0.040 & 1.308 & 1.013 & 1.689 \\
\hline BMI (5-point OR) & 0.069 & & & 0.861 & 0.733 & 1.011 \\
\hline Drainage & 0.083 & Yes vs. no & & 0.584 & 0.319 & 1.072 \\
\hline Age (10-year OR) & 0.262 & & & 1.047 & 0.966 & 1.136 \\
\hline Mesh size (10-point OR) & 0.597 & & & 0.985 & 0.930 & 1.043 \\
\hline
\end{tabular}

sac from the inguinal canal, whereas a medial hernia defect will persist as evagination of the transversalis fascia once repaired. It should therefore be reduced to prevent it from being filled with serous fluid. Various techniques have been proposed in the literature to that effect. Reddy [4] recommends the inversion of the extended transversalis fascia and fixation with tacks to the pubic bone. Technically, this is only feasible through the use of permanent tacks. Besides, 
the use of tacks can trigger chronic pain. Berney [5] recommends using a Röder loop, where the inverted transversalis fascia is ligated with the Röder loop such that the entrance to the medial hernia sac is closed and the sac completely reduced. Alternatively, the inverted transversalis fascia can be fixed to Cooper's ligament with a suture and the hernia sac completely reduced in the same manner [25]. Using these techniques the problem of seroma formation can be completely prevented for a large medial inguinal hernia in both TEP and TAPP. Therefore this technique is urgently recommended in the guidelines $[1,2]$.

The aforementioned findings also highlight the potential role of drain placement for prevention of seromas. To date, only very few publications recommend the use of a drain $[19,20]$. The results of multivariable analysis demonstrate a trend towards a protective role for a drain in reducing seroma formation after TAPP. But as arguments against drains complications and pain induced by drains must be mentioned. Since drains are used more commonly for TEP [25], this might also explain the difference in the seroma rate for TAPP vs. TEP.

There are reports in the literature that could explain the higher seroma rates identified on using glues. An experimental study with the cyanoacrylate-based tissue adhesives Glubran and Ifabond demonstrated that synthetic glues triggered evident seroma formation in the form of an inflammatory reaction [26]. This was caused by the toxic property of cyanoacrylate which, as far as possible, is reduced by means of chemical changes [26]. Some studies have reported that the fibrin glue Tisseel/Tissucol is associated with higher rates of seroma formation than staple fixation although that finding has been inconsistent [27]. It is likely that the avoidance of drop formation and local accumulation by spraying the fibrin sealant reduces the incidence of seroma formation [27].

The present study has a number of limitations. The registry does not contain any data on how the peritoneum was closed. Nor is any information given on whether the diagnosis "seroma" was based on physical examination or radiography. The possibility of confusing seromas with early hernia recurrences cannot be ruled out either.

In summary, it has been demonstrated that the seroma rate in male patients with TAPP repair of primary unilateral inguinal hernia is negatively influenced by mesh fixation with tacks or glue. Non-mesh fixation was associated with the lowest seroma rate. This can also explain the difference in the seroma rate between TEP and TAPP to the disadvantage of the latter technique since for TAPP mesh fixation continues to be used in $65 \%$ of cases. But the evidence-based data demonstrate that, as for TEP, mesh fixation should generally only be used, in TAPP too, for hernia defects of more than $3 \mathrm{~cm}$ (EHS LIII, MIII), and in particular for medial hernias. Otherwise, seroma formation is commonly encountered for large inguinal hernias, and especially for large medial inguinal hernias. Therefore medial defects should either be secured with a suture to Cooper's ligament or reduced with a Roeder loop. Furthermore, there appears to be a trend towards a positive role for drain placement after TAPP in reducing seroma formation.

Acknowledgements Ferdinand Köckerling received grants to fundthe Herniamed Registry from Johnson \& Johnson, Norderstedt; KarlStorz, Tuttlingen; PFM medical, Cologne; Dahlhausen, Cologne; BBraun, Tuttlingen; MenkeMed, Munich; and Bard, Karlsruhe.

\section{Compliance with ethical standards}

Disclosures R. Bittner, D. Adolf, R. Fortelny, H. Niebuhr, F. Mayer, C. Schug-Pass have no conflicts of interest or financial ties to disclose.

Open Access This article is distributed under the terms of the Creative Commons Attribution 4.0 International License (http://creativeco mmons.org/licenses/by/4.0/), which permits unrestricted use, distribution, and reproduction in any medium, provided you give appropriate credit to the original author(s) and the source, provide a link to the Creative Commons license, and indicate if changes were made.

\section{Herniamed study group}

\section{Scientific board}

Köckerling, Ferdinand (Chairman) (Berlin); Bittner, Reinhard (Rottenburg); Fortelny, René (Wien); Jacob, Dietmar (Berlin); Koch, Andreas (Cottbus); Kraft, Barbara (Stuttgart); Kuthe, Andreas (Hannover); Lammers, Bernhard (Neuss); Lippert, Hans (Magdeburg); Lorenz, Ralph (Berlin); Mayer, Franz (Salzburg); Niebuhr, Henning (Hamburg); Peiper, Christian (Hamm); Pross, Matthias (Berlin); Reinpold, Wolfgang (Hamburg); Simon, Thomas (Weinheim); Stechemesser, Bernd (Köln); Unger, Solveig (Chemnitz); Weyhe, Dirk (Oldenburg); Zarras, Konstantinos (Düsseldorf).

\section{Participants}

Ahmetov, Azat (Saint-Petersburg); Alapatt, Terence Francis (Frankfurt/Main); Albayrak, Nurretin (Herne); Amann, Stefan (Neuendettelsau); Anders, Stefan (Berlin); Anderson, Jürina (Würzburg); Antoine, Dirk (Leverkusen); Apfelstedt, Heinrich (Solingen); Arndt, Anatoli (Elmshorn); Aschenbrenner, Michael (Spittal/Drau); Asperger, Walter (Halle); Avram, Iulian (Saarbrücken); Baikoglu-Endres, Corc (Weißenburg i. Bay.); Bandowsky, Boris (Damme); Barkus; Jörg (Velbert); Becker, Matthias (Freital); Behrend, Matthias (Deggendorf); Berkhoff, Christian (Fulda); Beuleke, Andrea (Burgwedel); Birk, Dieter (Bietigheim-Bissingen); Bittner, Reinhard (Rottenburg); Blaha, Pavel (Zwiesel); Blumberg, 
Claus (Lübeck); Böckmann, Ulrich (Papenburg); Böhle, Arnd Steffen (Bremen); Bolle, Ludger (Berlin); Borchert, Erika (Grevenbroich); Born, Henry (Leipzig); Brabender, Jan (Köln); Breitenbuch von, Philipp (Radebeul); Brož, Miroslav (Ebersbach); Brückner, Torsten (Gießen); Brütting, Alfred (Erlangen); Buchert, Annette (Mallersdorf-Pfaffenberg); Buchholz, Torsten (Aurich); Budzier, Eckhard (Meldorf); Burchett, Bert (Teterow); Burghardt, Jens (Rüdersdorf); Cejnar, Stephan-Alexander (München); Chirikov, Ruslan (Dorsten); Claußnitzer, Christian (Ulm); Comman, Andreas (Bogen); Crescenti, Fabio (Verden/Aller); Daniels, Thies (Hamburg); Dapunt, Emanuela (Bruneck); Decker, Georg (Berlin); Demmel, Michael (Arnsberg); Descloux, Alexandre (Baden); Deusch, Klaus-Peter (Wiesbaden); Dick, Marcus (Neumünster); Dieterich, Klaus (Ditzingen); Dietz, Harald (Landshut); Dittmann, Michael (Northeim); Drummer, Bernhard (Forchheim); Eckermann, Oliver (Luckenwalde); Eckhoff (Jörn /Hamburg); Ehmann, Frank (Grünstadt); Eisenkrein, Alexander (Düren); Elger, Karlheinz (Germersheim); Engelhardt, Thomas (Erfurt); Erichsen, Axel (Friedrichshafen); Eucker, Dietmar (Bruderholz); Fackeldey, Volker (Kitzingen); Faddah, Yousif (Kamenz); Farke, Stefan (Delmenhorst); Faust, Hendrik (Emden); Federmann, Georg (Seehausen); Fiedler, Michael (Eisenberg); Fikatas, Panagiotis (Berlin); Firl, Michaela (Perleberg); Fischer, Ines (Wiener Neustadt); Fleischer, Sabine (Dinslaken); Fortelny, René H. (Wien); Franczak, Andreas (Wien); Franke, Claus (Düsseldorf); Frankenberg von, Moritz (Salem); Frehner, Wolfgang (Ottobeuren); Friedhoff, Klaus (Andernach); Friedrich, Jürgen (Essen); Frings, Wolfram (Bonn); Fritsche, Ralf (Darmstadt); Frommhold, Klaus (Coesfeld); Frunder, Albrecht (Tübingen); Fuhrer, Günther (Reutlingen); Garlipp, Ulrich (Bitterfeld-Wolfen); Gassler, Harald (Villach); Gawad, Karim A. Frankfurt/Main); Gehrig, Tobias (Sinsheim); Gerdes, Martin (Ostercappeln); Germanov, German (Halberstadt); Gilg, Kai-Uwe (Hartmannsdorf); Glaubitz, Martin (Neumünster); Glauner-Goldschmidt, Kerstin (Werne); Glutig, Holger (Meissen); Gmeiner, Dietmar (Bad Dürrnberg); Göring, Herbert (München); Grebe, Werner (Rheda-Wiedenbrück); Grothe, Dirk (Melle); Günther, Thomas (Dresden); Gürtler, Thomas (Zürich); Hache, Helmer (Löbau); Hämmerle, Alexander (Bad Pyrmont); Haffner, Eugen (Hamm); Hain, Hans-Jürgen (Gross-Umstadt); Halter, Christian Jörn (Recklinghausen); Hammans, Sebastian (Lingen); Hampe, Carsten (Garbsen); Hanke, Stefan (Halle); Harrer, Petra (Starnberg); Hartung, Peter (Werne); Heinzmann, Bernd (Magdeburg); Heise, Joachim Wilfried (Stolberg); Heitland, Tim (München); Helbling, Christian (Uznach/Schweiz); Hellinger, Achim (Fulda); Hempen, Hans-Günther (Cloppenburg); Henneking, Klaus-Wilhelm (Bayreuth); Hennes, Norbert (Duisburg); Herdter, Christian (Gelsenkirchen); Hermes, Wolfgang (Weyhe); Herzing, Holger (Höchstadt); Hessler, Christian (Bingen); Heuer,
Matthias (Herten); Hildebrand, Christiaan (Langenfeld); Höferlin, Andreas (Mainz); Hoffmann, Henry (Basel); Hoffmann, Michael (Kassel); Hofmann, Eva M. (Frankfurt/ Main); Horbach, Thomas (Fürth); Hornung, Frederic (Wolfratshausen); Hudak, Attila (Suhl); Hübel-Abe, Jan (Ilmenau); Hügel, Omar (Hannover); Hüttemann, Martin (Oberhausen); Hüttenhain, Thomas (Mosbach); Hunkeler, Rolf (Zürich); Imdahl, Andreas (Heidenheim); Iseke, Udo (Duderstadt); Isemer, Friedrich-Eckart (Wiesbaden); Jablonski, Herbert Gustav (Sögel); Jacob, Dietmar (Berlin); JansenWinkeln, Boris (Leipzig); Jantschulev, Methodi (Waren); Jenert, Burghard (Lichtenstein); Jugenheimer, Michael (Herrenberg); Junge, Karsten (Aachen); Kaaden, Stephan (Neustadt am Rübenberge); Käs, Stephan (Weiden); Kahraman, Orhan (Hamburg); Kaiser, Christian (Westerstede); Kaiser, Gernot Maximilian (Kamp-Lintfort); Kaiser, Stefan (Kleinmachnow); Karch, Matthias (Eichstätt); Kasparek, Michael S. (München); Kastl, Sigrid (Braunau am Inn); Keck, Heinrich (Wolfenbüttel); Keller, Hans W. (Bonn); Kewer, Jans Ludolf (Tuttlingen); Kienzle, Ulrich (Karlsruhe); Kipfmüller, Brigitte (Köthen); Kirsch, Ulrike (Oranienburg); Klammer, Frank (Ahlen); Klatt, Richard (Hagen); Klein, KarlHermann (Burbach); Kleist, Sven (Berlin); Klobusicky, Pavol (Bad Kissingen); Kneifel, Thomas (Datteln); Knolle, Winfried (Pritzwalk); Knoop, Michael (Frankfurt/Oder); Knotter, Bianca (Mannheim); Koch, Andreas (Cottbus); Koch, Andreas (Münster); Köckerling, Ferdinand (Berlin); Köhler, Gernot (Linz); König, Oliver (Buchholz); Kornblum, Hans (Tübingen); Krämer, Dirk (Bad Zwischenahn); Kraft, Barbara (Stuttgart); Kratsch, Barthel (Dierdorf/ Selters); Krausbeck, Matthias (Schwerin); Kreissl, Peter (Ebersberg); Krones, Carsten Johannes (Aachen); Kronhardt, Heinrich (Neustadt am Rübenberge); Kruse, Christinan (Aschaffenburg); Kube, Rainer (Cottbus); Kühlberg, Thomas (Berlin); Kühn, Gert (Freiberg); Kuhn, Roger (Gifhorn); Kusch, Eduard (Gütersloh); Kuthe, Andreas (Hannover); Ladberg, Ralf (Bremen); Ladra, Jürgen (Düren); Lahr-Eigen, Rolf (Potsdam); Lainka, Martin (Wattenscheid); Lalla, Thomas (Oschersleben); Lammers, Bernhard J. (Neuss); Lancee, Steffen (Alsfeld); Lange, Claas (Berlin); Langer, Claus (Göttingen); Laps, Rainer (Ehringshausen); Larusson, Hannes Jon (Pinneberg); Lauschke, Holger (Duisburg); Lechner-Puschnig, Marina (Klagenfurt am Wörthersee/Österreich); Leher, Markus (Schärding); Leidl, Stefan (Waidhofen/Ybbs); Leisten, Edith (Köln); Lenz, Stefan (Berlin); Liedke, Marc Olaf (Heide); Lienert, Mark (Duisburg); Limberger, Andreas (Schrobenhausen); Limmer, Stefan (Würzburg); Locher, Martin (Kiel); Loghmanieh, Siawasch (Viersen); Lorenz, Ralph (Berlin); Luedtke, Clinton (Kusel); Luther, Stefan (Wipperfürth); Luyken, Walter (SulzbachRosenberg); Mallmann, Bernhard (Krefeld); Manger, Regina (Schwabmünchen); Maurer, Stephan (Münster); May, Jens Peter (Schönebeck); Mayer, Franz (Salzburg); Mayer, Jens 
(Schwäbisch Gmünd); Mellert, Joachim (Höxter); Menzel, Ingo (Weimar); Meurer, Kirsten (Bochum); Meyer, Moritz (Ahaus); Mirow, Lutz (Zwickau); Mittag-Bonsch, Martina (Crailsheim); Möbius, Ekkehard (Braunschweig); MörderKöttgen, Anja (Freiburg); Moesta, Kurt Thomas (Hannover); Mugomba, Gilbert (Dannenberg); Moldenhauer, Ingolf (Braunschweig); Morkramer, Rolf (Radevormwald); Mosa, Tawfik (Merseburg); Müller, Hannes (Schlanders); Müller, Volker (Nürnberg); Münzberg, Gregor (Berlin); Murr, Alfons (Vilshofen); Mussack, Thomas (St. Gallen); Nartschik, Peter (Quedlinburg); Nasifoglu, Bernd (Ehingen); Neumann, Jürgen (Haan); Neumeuer, Kai (Paderborn); Niebuhr, Henning (Hamburg); Nix, Carsten (Walsrode); Nölling, Anke (Burbach); Nostitz, Friedrich Zoltán (Mühlhausen); Obermaier (Straubing); Öz-Schmidt, Meryem (Hanau); Oldorf, Peter (Usingen); Olivieri, Manuel (Pforzheim); Passon, Marius (Freudenberg); Pawelzik, Marek (Hamburg); Pein, Tobias (Hameln); Peiper, Christian (Hamm); Peiper, Matthias (Essen); Pertl, Alexander (Spittal/Drau); Philipp, Mark (Rostock); Pickart, Lutz (Bad Langensalza); Pizzera, Christian (Graz); Pöllath, Martin (Sulzbach-Rosenberg); Pöschmann, Enrico (Thalwil); Possin, Ulrich (Laatzen); Prenzel, Klaus (Bad Neuenahr-Ahrweiler); Pröve, Florian (Goslar); Pronnet, Thomas (Fürstenfeldbruck); Pross, Matthias (Berlin); Puff, Johannes (Dinkelsbühl); Rabl, Anton (Passau); Raggi, Matthias Claudius (Stuttgart); Rapp, Martin (Neunkirchen); Reck, Thomas (Püttlingen); Reinpold, Wolfgang (Hamburg); Renter, Marc Alexander (Moers); Reuter, Christoph (Quakenbrück); Radke, Alexander (Thun/Zweisimmen); Richter, Jörg (Winnenden); Riemann, Kerstin (Alzenau-Wasserlos); Riesener, Klaus-Peter (Marl); Rodehorst, Anette (Otterndorf); Roehr, Thomas (Rödental); Rössler, Michael (Rüdesheim am Rhein); Roncossek (Bremerhaven); Rosniatowski, Rolland (Marburg); Roth Hartmut (Nürnberg); Sardoschau, Nihad (Saarbrücken); Sauer, Gottfried (Rüsselsheim); Sauer, Jörg (Arnsberg); Seekamp, Axel (Freiburg); Seelig, Matthias (Bad Soden); Seidel, Hanka (Eschweiler); Seiler, Christoph Michael (Warendorf); Seltmann, Cornelia (Hachenburg); Senkal, Metin (Witten); Shamiyeh, Andreas (Linz); Shang, Edward (München); Siemssen, Björn (Berlin); Sievers, Dörte (Hamburg); Silbernik, Daniel (Bonn); Simon, Thomas (Weinheim); Sinn, Daniel (Olpe); Sinner, Guy (Merzig); Sinning, Frank (Nürnberg); Smaxwil, Constatin Aurel (Stuttgart); Sörensen, Björn (Lauf an der Pegnitz): Sucke, Jochen Markus (Gießen); Syga, Günter (Bayreuth); Schabel, Volker (Kirchheim/Teck); Schadd, Peter (Euskirchen); Schassen von, Christian (Hamburg); Schattenhofer, Thomas (Vilshofen); Scheibel, Mike (Krefeld); Schelp, Lothar (Wuppertal); Scherf, Alexander (Pforzheim); Scheuerlein, Hubert (Paderborn); Scheyer, Mathias (Bludenz); Schilling, André (Kamen); Schimmelpenning, Hendrik (Neustadt in Holstein); Schinkel, Svenja (Kempten); Schmid, Michael
(Gera); Schmid, Thomas (Innsbruck); Schmidt, Ulf (Mechernich); Schmitz, Heiner (Jena); Schmitz, Ronald (Altenburg); Schöche, Jan (Borna); Schoenen, Detlef (Schwandorf); Schrittwieser, Rudolf (Bruck an der Mur); Schroll, Andreas (München); Schubert, Daniel (Saarbrücken); Schüder, Gerhard (Wertheim); Schürmann, Rainer (Steinfurt); Schultz, Christian (Bremen-Lesum); Schultz, Harald (Landstuhl); Schulze, Frank P. Mülheim an der Ruhr); Schulze, Thomas (Dessau-Roßlau); Schumacher, FranzJosef (Oberhausen); Schwab, Robert (Koblenz); Schwandner, Thilo (Lich); Schwarz, Jochen Günter (Rottenburg); Schymatzek, Ulrich (Eitorf); Spangenberger, Wolfgang (Bergisch-Gladbach); Sperling, Peter (Montabaur); Staade, Katja(Düsseldorf); Staib, Ludger (Esslingen); Staikov, Plamen (Frankfurt am Main); Stamm, Ingrid (Heppenheim); Stark, Wolfgang (Roth); Stechemesser, Bernd (Köln); Steinhilper, Uz (München); Stengl, Wolfgang (Nürnberg); Stern, Oliver (Hamburg); Stöltzing, Oliver (Meißen); Stolte, Thomas (Mannheim); Stopinski, Jürgen (Schwalmstadt); Stratmann, Gerald (Goch); Straßburger, Harald (Alfeld); Stubbe, Hendrik (Güstrow/); Stülzebach, Carsten (Friedrichroda); Tepel, Jürgen (Osnabrück); Terzić, Alexander (Wildeshausen); Teske, Ulrich (Essen); Thasler, Wolfgang (München); Tichomirow, Alexej (Brühl); Tillenburg, Wolfgang (Marktheidenfeld); Timmermann, Wolfgang (Hagen); Tomov, Tsvetomir (Koblenz; Train, Stefan H. (Gronau); Trauzettel, Uwe (Plettenberg); Triechelt, Uwe (Langenhagen); Ulbricht, Wolfgang (Breitenbrunn); Ulcar, Heimo (Schwarzach im Pongau); Ungeheuer, Andreas (München); Unger, Solveig (Chemnitz); Utech, Markus (Gelsenkirchen); Verweel, Rainer (Hürth); Vogel, Ulrike (Berlin); Voigt, Rigo (Altenburg); Voit, Gerhard (Fürth); Volkers, Hans-Uwe (Norden); Volmer, Ulla (Berlin); Vossough, Alexander (Neuss); Wallasch, Andreas (Menden); Wallner, Axel (Lüdinghausen); Warscher, Manfred (Lienz); Warwas, Markus (Bonn); Weber, Jörg (Köln); Weber, Uwe (Eggenfelden); Weihrauch, Thomas (Ilmenau); Weiß, Heiko (Aue); Weiß, Johannes (Schwetzingen); Weißenbach, Peter (Neunkirchen); Werner, Uwe (Lübbecke-Rahden); Wessel, Ina (Duisburg); Weyhe, Dirk (Oldenburg); Wicht, Sebastian (Bützow); Wieber, Isabell (Köln); Wiens, Matthias (Affoltern); Wiesmann, Aloys (Rheine); Wiesner, Ingo (Halle); Withöft, Detlef (Neutraubling); Woehe, Fritz (Sangerhausen); Wolf, Claudio (Neuwied); Wolkersdörfer, Toralf (Pößneck); Yaksan, Arif (Wermelskirchen); Yildirim, Can (Lilienthal); Yildirim, Selcuk (Berlin); Zarras, Konstantinos (Düsseldorf); Zeller, Johannes (Waldshut-Tiengen); Zhorzel, Sven (Agatharied); Zuz, Gerhard (Leipzig); 


\section{References}

1. Bittner R, Arregui ME, Bisgaard T, Dudai M, Ferzli GS, Fitzgibbons RL, Fortelny RH, Klinge U, Köckerling F, Kuhry E, Kukleta J, Lomanto D, Misra MC, Montgomery A, Morales-Conde S, Reinpold W, Rosenberg J, Sauerland S, Schug-Pass C, Singh K, Timoney M, Weyhe D, Chowbey P (2011) Guidelines for laparoscopic (TAPP) and endoscopic (TEP) treatment of inguinal hernia [International Endohernia Society (IEHS)]. Surg Endosc 25(9):2773-2843. https://doi.org/10.1007/s00464-011-1799-6

2. Bittner R, Montgomery MA, Arregui E, Bansal V, Bingener J, Bisgaard T, Buhck H, Dudai M, Ferzli GS, Fitzgibbons RJ, Frotelny RH, Grimes KL, Klinge U, Köckerling F, Kumar S, Kukleta J, Lomanto D, Misra MC, Morales-Conde S, Reinpold W, Rosenberg J, Signh K, Timoney M, Weyhe D, Chowbey P (2015) International Endohernia Society update of guidelines on laparoscopic (TAPP) and endoscopic (TEP) treatment of inguinal hernia (International Endohernia Society). Surg Endosc 29(2):289-321. https://doi.org/10.1007/s00464-014-3917-8

3. Poelman MM, van den Heuvel B, Deelder JD, Abis GS, Beudeker N, Bittner R, Campanelli G, van Dam D, Dwars BJ, Eker HH, Fingerhut A, Khatkov I, Köckerling F, Kukleta JF, Miserez M, Montgomery A, Munoz Brands RM, Morales-Conde S, Muysoms FE, Soltes M, Tromp W, Yavuz Y, Bonjer HJ (2013) EAES consensus development conference on endoscopic repair of groin. Hernias Surg Endosc 27(10):3505-3519. https://doi.org/10.1007/ s00464-013-3001-9

4. Reddy VM, Sutton CD, Bloxham L, Garcea G, Ubhi SS, Robertson GS (2007) Laparoscopic repair of direct inguinal hernia: a new technique that reduces the development of postoperative seroma. Hernia 11:393-396. https://doi.org/10.1007/s1002 9-007-0233-4

5. Berney CR (2012) The Endoloop technique for the primary closure of direct inguinal hernia defect during the endoscopic totally extraperitoneal approach. Hernia 16:301-305. https://doi. org/10.1007/s10029-011-0892-Z

6. Schmedt CG, Sauerland S, Bittner R (2005) Comparison of endoscopic procedures vs Lichtenstein and other open mesh techniques for inguinal hernia repair. Surg Endosc 19:188-199. https://doi. org/10.1007/s00464-004-9126-0

7. Panse M, Deshpande N, Mandhane A, Bhalerao P (2013) Seroma prevention technique following endoscopic direct inguinal hernia repair. J Evol Med Dental Sci 2:4928-4932

8. Köckerling F, Bittner R, Jacob DA, Seidelmann L, Keller T, Adolf D, Kraft B, Kuthe A (2015) TEP versus TAPP: comarison of the perioperative outcome in 17,587 patients with a primary unilateral inguinal hernia. Surg Endosc 29:3750-3760. https://doi. org/10.1007/s00464-015-4150-9

9. Köckerling F, Stechemesser B, Hukauf M, Kuthe A, Schug-Pass C (2015) TEP versus Lichtenstein: which technique is better for the repair of primary unilateral inguinal hernias in men? Surg Endosc 30(8):3304-3313. https://doi.org/10.1007/s00464-014-4603-1

10. Lau H, Lee F (2003) Seroma following endoscopic extraperitoneal inguinal hernioplasty. Surg Endosc 17:1773-1777. https:// doi.org/10.1007/s00464-002-8771-4

11. Choi YY, Kim Z, Hur KY (2011) Swelling after laparoscopic total extraperitoneal repair of inguinal hernias: review of one surgeon's experience in 1,065 cases. World J Surg 35:43-46. https://doi. org/10.1007/s00268-010-0843-3

12. Bittner R, Schmedt CG, Leibl BJ, Schwarz J (2011) Early postoperative and one year results of a randomized controlled trial comparing the impact of extralight titanized polypropylene mesh and traditional heavyweight polypropylene mesh on pain and seroma production in laparoscopic hernia repair (TAPP). World J Surg 35:1791-1797. https://doi.org/10.1007/s00268-011-1148-x
13. Currie A, Andrew H, Tonsi A, Hurley PR, Taribagil S (2012) Lightweight versus heavyweight mesh in laparoscopic inguinal hernia repair: a meta-analysis. Surg Endosc 26(8):2126-2133. https://doi.org/10.1007/ss00464-012-2179-6

14. Garg P, Rajagopal M, Varghese V, Ismail M (2009) Laparoscopic total extraperitoneal inguinal hernia repair with nonfixation of the mesh for 1,692 hernias. Surg Endosc 23(6):1241-1245. https ://doi.org/10.1007/ss00464-008-0137-0

15. Teng YL, Pan SM, Liu YL, Yang KH, Zhang YC, Tian JH, Han JX (2011) A meta-analysis of randomized controlled trials of fixation versus nofixation of mesh in laparoscopic total extraperitoneal inguinal hernia repair. Surg Endosc 25(9):2849-2858. https://doi. org/10.1007/s00464-011-1668-3

16. Shah NS, Fullwood C, Siriwardena AK, Sheen AJ (2014) Mesh fixation at laparoscopic inguinal hernia repair: a metaanalysis comparing tissue glue and tack fixation. World J Surg 38(10):2558-2570. https://doi.org/10.1007/s00268-014-2547-6

17. Li J, Ji Z, Zhang W (2015) Staple fixation against adhesive fixation in laparoscopic inguinal hernia repair: a meta-analysis of randomized controlled trials. Surg Laparosc Endosc Percutan Tech 25(6):471-477. https://doi.org/10.1097/SLE.0000000000000214

18. Antoniou SA, Köhler G, Antoniou GA, Muysoms FE, Pointner R, Granderath FA (2016) Meta-analysis of randomized trials comparing nonpenetrating vs mechanical mesh fixation in laparoscopic inguinal hernia repair. Am J Surg. https://doi.org/10.1016/j.amjsu rg.2015.06.008

19. Ismail M, Garg M, Rajagopal M, Garg P (2009) Impact of closedsuction drain in preperitoneal space on the incidence of seroma formation after laparoscopic total extraperitoneal inguinal hernia repair. Surg Laparosc Endosc Percutan Tech 19(3):263-266. https ://doi.org/10.1097/SLE.0b013e3181a4d0e1

20. Gao D, Wei S, Zhai C, Chen J, Li M, Gu C, Wu H (2015) Clinical research of preperitoneal drainage after endoscopic totally extraperitoneal inguinal hernia repair. Hernia 19:789-794. https://doi. org/10.1007/s10029-014-1310-0

21. Stechemesser B, Jacob DA, Schug-Pass C, Köckerling F (2012) Herniamed: an internet-based registry for outcome research in hernia surgery. Hernia 16(3):269-276. https://doi.org/10.1007/ s10029-012-0908-3

22. Haapaniemi S, Nilsson E (2002) Recurrence and pain three years after groin hernia repair: validation of postal questionnaire and selective physical examination as a method of follow up. Eur J Surg 168(1):22-28. https://doi.org/10.1080/110241502317307535

23. Miserez M, Alexandre JH, Campanelli G, Corcione F, Cuccurullo D, Pascual MH, Hoeferlin A, Kingsnorth AN, Mandala V, Palot JP, Schumpelick V, Simmermacher RK, Stoppa R, Flament JB (2007) The European hernia society groin hernia classification: simple and easy to remember. Hernia 11(2):113-116. https://doi. org/10.1007/s10029-007-0198-3

24. Mayer F, Niebuhr H, Lechner M, Dinnewitzer A, Köhler G, Hukauf M, Fortelny RH, Bittner R, Köckerling F (2016) When is mesh fixation in TAPP-repair of primary inguinal hernia repair necessary? The register-based analysis of 11,230 cases. Surg Endosc 30(10):4363-4371. https://doi.org/10.1007/s00464-016-4754-8

25. Köckerling F (2017) Evidence-based TEP technique. Chirurg. https://doi.org/10.1007/s00104-016-0360-5

26. Pascual G, Sotomayor S, Rodriguez M, Pérez-Köhler B, Kühnhardt A, Fernández-Gutiérrez M, San Román J, Bellón JM (2016) Cytotoxicity of cyanoacrylate-based tissue adhesives and shortterm preclinical in vivo biocompatibility in abdominal hernia repair. PLoS ONE 11(6):e0157920. https://doi.org/10.1371/journ al.pone. 0157920

27. Fortelny RH, Petter-Puchner AH, Glaser KS, Redl H (2012) Use of fibrin sealant (Tisseel/Tissucol) in hernia repair: a systematic review. Surg Endosc 26(7):1803-1812. https://doi.org/10.1007/ s00464-012-2156.0 